Jurnal Ilmu Ilmu Agribisnis: Journal of Agribusiness Science, 9(3), Agustus 2021

\title{
POLA KONSUMSI IKAN SEGAR OLEH RUMAH TANGGA DI KOTA BANDAR LAMPUNG
}

\author{
(The Consumption Pattern of Fresh Fish by Households in Bandar Lampung City)
}

M. Ryan Afif Marifza Syarif, Dwi Haryono, Suriaty Situmorang

Jurusan Agribisnis, Fakultas Pertanian, Universitas Lampung, J1. Prof. Dr. Soemantri Brojonegoro No. 1 Bandar Lampung, 35145, e-mail: dwi.haryono@fp.unila.ac.id

\begin{abstract}
This research aims to know the amount of daily fresh fish consumption by households, fresh fish consumption pattern, and factors that influence the consumption in Bandar Lampung City. The data in this research were analyzed descriptively and qualitatively. The locations and 54 respondents of this research were determined purposively, at Sukarame Village, Beringin Raya Village, and Panjang Utara Village, with the total respondents of 20,19, and 15 households respectively. The results of this research showed that the average of daily fresh fish consumption in Bandar Lampung City was 26.61 grams protein per household. Fresh fish consumption pattern included the kind of the fish was freshwater catfish, the frequency of fresh fish consumption was 4.10-6.00 kg per month; and place to buy fresh fish was traditional markets. Factors that influence the fresh fish consumption in Bandar Lampung City were price of fresh fish, the number of household members and middle economy degree.
\end{abstract}

Key words: consumption pattern, factors, fresh fish consumption

\section{PENDAHULUAN}

Pola konsumsi suatu masyarakat merupakan salah satu indikator untuk mengetahui tingkat kesejahteraan masyarakat tersebut. Badan Pusat Statistik (2007) mendefinisikan pola konsumsi rumah tangga sebagai proporsi pengeluaran rumah tangga yang dialokasikan untuk kebutuhan pangan dan non pangan. Apabila pengeluaran rumah tangga untuk kebutuhan pangan lebih besar dari kebutuhan non pangan, maka dapat dinyatakan bahwa tingkat kesejahteraan rumah tangga tersebut rendah (Sukiyono, Cahyadinata, dan Sriyoto 2008).

Pengeluaran masyarakat Indonesia pada tahun 2016 untuk bahan makanan $(51,61 \%)$ lebih besar dibandingkan dengan bukan bahan makanan (48,39\%) (Badan Pusat Statistik 2017). Berdasarkan data tersebut, maka dapat dinyatakan bahwa tingkat kesejahteraan masyarakat Indonesia relatif rendah. Hal ini menggambarkan kondisi pendapatan masyarakat yang terbatas. Rumah tangga akan mementingkan konsumsi pangan, sehingga pada kelompok masyarakat dengan pendapatan rendah, sebagian besar pendapatan digunakan untuk memenuhi kebutuhan makanan.

Salah satu kebutuhan pangan masyarakat adalah protein. Protein dapat diperoleh dari beberapa kelompok komoditas, yaitu padi-padian, ikan, daging, telur dan susu, serta kacang-kacangan
(Budianto 2009). Sumber makanan yang mengandung zat gizi protein dikenal sebagai sumber protein nabati dan sumber protein hewani. Kacang-kacangan dan beras merupakan sumber protein nabati, sedangkan daging, ikan, telur, dan susu merupakan sumber protein hewani. Protein diperlukan oleh tubuh sebagai pembentuk jaringan baru dalam masa pertumbuhan dan perkembangan tubuh sepanjang hidup serta memperbaiki jaringan yang rusak (Indriani 2015). Berdasarkan manfaatmanfaat protein tersebut, maka masyarakat perlu mengonsumsi beragam jenis makanan yang mengandung protein.

Rata-rata konsumsi protein di Indonesia tahun 2016 sebesar 46,99 gram protein (Badan Pusat Statistik 2017), dimana Provinsi Lampung dari tahun 2014-2016 berada pada urutan ketujuh terbawah di Indonesia setelah Provinsi Papua, Maluku Utara, Nusa Tenggara Timur, Maluku, Papua Barat dan Kalimantan Utara. Rata-rata konsumsi protein Provinsi Lampung adalah terendah bila dibandingkan dengan provinsi lainnya yang ada di Pulau Sumatera.

Kota Bandar Lampung merupakan pusat perekonomian yang didukung oleh berbagai fasilitas umum, yaitu pasar yang ramai, infrastruktur yang memadai, dukungan fasilitas transportasi yang lengkap dan lembaga penunjang ekonomi yang lengkap. Sebagai ibukota provinsi, 
Kota Bandar Lampung memiliki jumlah penduduk yang cukup tinggi. Jumlah penduduk Kota Bandar Lampung pada tahun 2015 adalah 979.287 jiwa (Badan Pusat Statistik Kota Bandar Lampung 2017). Peningkatan jumlah penduduk yang terjadi setiap tahun akan berdampak pada peningkatan konsumsi masyarakat, termasuk konsumsi ikan.

Konsumsi protein hewani masyarakat Kota Bandar Lampung melalui ikan segar merupakan yang paling banyak dibandingkan dengan daging, telur, dan susu yaitu 7,21 gram/kapita/hari, atau sebesar 43 persen dari total konsumsi makanan protein hewani (Badan Pusat Statistik Kota Bandar Lampung 2017). Meskipun tingkat konsumsi ikan masyarakat di Kota Bandar Lampung cukup tinggi dibandingkan dengan makanan protein hewani yang lainnya, namun konsumsi tersebut belum cukup untuk memenuhi standar konsumsi ikan yang telah ditetapkan oleh Organisasi Pangan dan Pertanian Dunia (FAO), yaitu 30 kilogram/kapita/ tahun atau 82,19 gram/kapita/hari (Virgantari dkk 2011). Hal ini menunjukkan bahwa konsumsi ikan masyarakat di Kota Bandar Lampung baru mencapai 10,15 persen dari konsumsi ikan yang ideal.

Rendahnya konsumsi ikan masyarakat Kota Bandar Lampung tentu tidak sesuai dengan Instruksi Presiden Nomor 1 Tahun 2017 tentang Gerakan Masyarakat Hidup Sehat (Germas) yang dimaksudkan dalam rangka perbaikan pola makan masyarakat untuk meningkatkan gizi masyarakat dengan mengkonsumsi ikan (Kementerian Kesehatan Republik Indonesia 2017). Untuk itu, penelitian ini dilakukan untuk mengetahui jumlah konsumsi ikan segar per kapita per hari di Kota Bandar Lampung, mengetahui pola konsumsi ikan segar oleh masyarakat di Kota Bandar Lampung, dan mengetahui faktor-faktor yang memengaruhi konsumsi ikan segar di Kota Bandar Lampung.

\section{METODE PENELITIAN}

Penelitian ini dilakukan di Kota Bandar Lampung pada Maret tahun 2019. Lokasi ini dipilih secara sengaja (purposive) dengan pertimbangan bahwa Kota Bandar Lampung adalah ibukota provinsi dan merupakan pusat kegiatan bisnis dan aktivitas ekonomi di Provinsi Lampung, serta memiliki jumlah penduduk cukup besar, yaitu sebanyak 979.287 jiwa (Badan Pusat Statistik Kota Bandar Lampung 2017). Selain itu, keadaan ekonomi dan gaya hidup masyarakat di Kota Bandar Lampung lebih beragam dibandingkan kabupaten atau kota lainnya. Oleh karena itu, Kota Bandar Lampung merupakan konsumen potensial untuk konsumsi ikan. Lokasi penelitian selanjutnya dibagi menjadi tiga wilayah berdasarkan kelas ekonomi, yaitu kelas bawah, menengah, dan atas.

Rumah tangga kelas bawah sebanyak 15 rumah tangga diwakili oleh kecamatan yang memiliki jumlah rumah tangga terbanyak yang berada pada kelompok prasejahtera dengan jumlah 3.025 orang. Rumah tangga kelas menengah sebanyak 19 rumah tangga diwakili oleh kecamatan yang memiliki jumlah rumah tangga terbanyak yang berada pada kelompok sejahtera II dengan jumlah 3.654 orang. Rumah tangga kelas atas sebanyak 20 rumah tangga diwakili oleh kecamatan yang memiliki jumlah rumah tangga terbanyak yang berada pada kelompok sejahtera III+ dengan jumlah 3.885 orang.

Penentuan jumlah sampel didasarkan pada rumus Isaac dan Michael (1995) dalam Sugiarto dkk (2001), yaitu:

$\mathrm{n}=\frac{\mathrm{NZ}^{2} \mathrm{~S}^{2}}{\mathrm{Nd}^{2}+\mathrm{Z}^{2} \mathrm{~S}^{2}}$

Keterangan :

$\mathrm{n}$ = Jumlah sampel

$\mathrm{N}=$ Jumlah populasi

$S^{2}=$ Variasi sampel $(5 \%)$

$\mathrm{Z}=$ Tingkat kepercayaan $(90 \%=1,645)$

$\mathrm{d}=$ Derajat penyimpangan $(5 \%)$

Jumlah sampel yang diperoleh dari persamaan (1) adalah:

$\mathrm{n}=\frac{(3.885+3.654+3.025)\left(1.645^{2}\right)(0,05)}{(3.885+3.654+3.025)\left(0,05^{2}\right)+\left(1.645^{2}\right)(0,05)}$

$\mathrm{n}=\frac{10.564\left(1.645^{2}\right)(0,05)}{10.564\left(0,05^{2}\right)+\left(1.645^{2}\right)(0,05)}$

$\mathrm{n}=54$

Rincian jumlah sampel untuk masing-masing wilayah $\left(\mathrm{n}_{1}\right)$ dihitung secara proposional dengan rumus (Nasir 1988):

$\mathrm{ni}=\frac{\mathrm{Ni}}{\mathrm{N}} \mathrm{n}$

Keterangan :

$\mathrm{ni} \quad=$ Jumlah sampel menurut stratum

$\mathrm{n} \quad=$ Jumlah sampel seluruhnya

$\mathrm{Ni} \quad=$ Jumlah populasi menurut stratum

$\mathrm{N} \quad=$ Jumlah populasi seluruhnya 
Responden atau sampel dalam penelitian ini adalah ibu rumah tangga yang berperan dalam pengambilan keputusan dalam mengonsumsi ikan segar. Sampel ditentukan berdasarkan rekomendasi dari aparatur kelurahan dan RT di masing-masing kelurahan. Sampel dipilih sebanyak 2 sampai 3 rumah tangga di masing-masing RT di setiap kelurahan. Sebanyak 15 rumah tangga di Kelurahan Panjang Utara, 19 rumah tangga di Kelurahan Beringin Raya, dan 20 rumah tangga di Kelurahan Sukarame.

Analisis deskriptif kuantitatif digunakan untuk mengetahui jumlah komsumsi ikan segar per kapita per hari di Kota Bandar Lampung, sedangkan analisis deskriptif kuantitatif digunakan untuk mengetahui pola komsumsi ikan segar oleh rumah tangga di Kota Bandar Lampung. Analisis faktorfaktor yang memengaruhi konsumsi ikan pada penelitian ini menggunakan regresi linier berganda, dan secara matematis dirumuskan dengan persamaan:

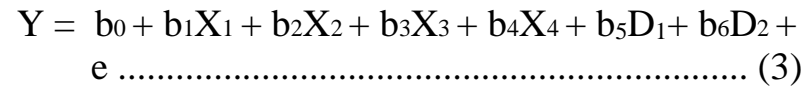

\section{Keterangan :}

$\mathrm{Y}=$ Konsumsi ikan (gram protein)

$\mathrm{b}_{0} \quad=$ Intersep

$\mathrm{b}_{1}-\mathrm{b}_{6}=$ Koefisien regresi

$\mathrm{X}_{1} \quad=$ Harga ikan segar (Rp/gram protein)

$\mathrm{X}_{2} \quad=$ Harga telur ayam (Rp/gram protein)

$\mathrm{X}_{3} \quad=$ Pendapatan keluarga (Rp/bulan)

$\mathrm{X}_{4} \quad=$ Jumlah anggota keluarga (orang)

$\mathrm{D}_{1} \quad=\mathrm{D}_{1}=1$ Tingkat ekonomi bawah, $\mathrm{D}_{1}=0$ tingkat ekonomi lainnya

$\mathrm{D}_{2} \quad=\mathrm{D}_{2}=1$ Tingkat ekonomi menegah, $\mathrm{D}_{2}=0$ tingkat ekonomi lainnya

e $\quad=$ Kesalahan acak

\section{HASIL DAN PEMBAHASAN}

Responden penelitian ini adalah ibu rumah tangga yang termasuk dalam keluarga sejahtera III+, sejahtera II, dan pra sejahtera, dengan jumlah responden sebanyak 54 orang. Karakteristik responden yang diteliti adalah umur, berat badan, tingkat pendidikan, pekerjaan, suku, jumlah anggota keluarga, dan tingkat pendapatan seperti yang disajikan pada Tabel 1 .

Selain tingkat pendidikan ibu rumah tangga, jenis pekerjaan ibu rumah tangga juga memengaruhi dalam mengonsumsi ikan. Responden pada penelitian ini memiliki jenis pekerjaan yang beragam. Namun, berdasarkan Tabel 1 diketahui bahwa dominan $(57,41 \%)$ responden bekerja sebagai ibu rumah tangga, sedangkan yang terendah adalah responden yang bekerja sebagai buruh dan dokter $(1,85 \%)$. Responden yang bekerja sebagai ibu rumah tangga memiliki peran utama dalam pengambilan keputusan dalam mengonsumsi ikan segar. Semakin tinggi pendidikan ibu rumah tangga, semakin memengaruhi referensi ibu rumah tangga dalam memilih ikan segar sebagai sumber protein hewani.

Tingkat pendidikan dibagi menjadi empat tingkatan, yaitu SD, SMP, SMA, dan Diploma atau Sarjana. Sebanyak 46,30 persen responden pada penelitian ini berpendidikan Diploma atau Sarjana. Responden dalam penelitian ini tergolong berpendidikan tinggi, karena berdomisili di kota. Ibu rumah tangga pada penelitian ini berada pada kategori umur 30 sampai 62 tahun. Jumlah anggota keluarga rumah tangga berkisar antara 2 sampai 7 orang.

Responden pada penelitian ini memiliki suku yang beragam, namun didominasi $(51,85 \%)$ oleh responden yang bersuku Jawa.

Tabel 1. Sebaran konsumen ikan segar berdasarkan karakteristik responden di Kota Bandar Lampung, tahun 2019

\begin{tabular}{|c|c|c|}
\hline $\begin{array}{l}\text { Karakteristik } \\
\text { Responden }\end{array}$ & $\begin{array}{l}\text { Jumlah } \\
\text { (Orang) }\end{array}$ & Persentase $(\%)$ \\
\hline \multicolumn{3}{|l|}{ Tingkat pendidikan : } \\
\hline $\mathrm{SD}$ & 5,00 & 9,26 \\
\hline SMP & 9,00 & 16,66 \\
\hline SMA & 15,00 & 27,78 \\
\hline Diploma/sarjana & 25,00 & 46,30 \\
\hline \multicolumn{3}{|l|}{ Jenis pekerjaan : } \\
\hline Ibu rumah tangga & 31,00 & 57,41 \\
\hline PNS & 13,00 & 24,10 \\
\hline Buruh & 1,00 & 1,85 \\
\hline Pegawai swasta & 4,00 & 7,41 \\
\hline Wirausaha & 4,00 & 7,41 \\
\hline Dokter & 1,00 & 1,85 \\
\hline \multicolumn{3}{|l|}{ Suku : } \\
\hline Lampung & 14,00 & 25,93 \\
\hline Batak & 1,00 & 1,85 \\
\hline Jawa & 28,00 & 51,85 \\
\hline Sunda & 4,00 & 7,41 \\
\hline Palembang & 4,00 & 7,41 \\
\hline Padang & 2,00 & 3,70 \\
\hline Bali & 1,00 & 1,85 \\
\hline \multicolumn{3}{|l|}{$\begin{array}{l}\text { Tingkat pendapatan } \\
\text { (Rupiah/bulan) : }\end{array}$} \\
\hline $2.000 .000-4.000 .000$ & 23,00 & 42,59 \\
\hline $4.000 .001-6.000 .000$ & 17,00 & 31,48 \\
\hline $6.000 .001-8.000 .000$ & 8,00 & 14,81 \\
\hline $8.000 .000-10.000 .000$ & 3,00 & 5,56 \\
\hline$>10.000 .000$ & 3,00 & 5,56 \\
\hline Rata-rata pendapatan & Rp 5.147 & \\
\hline
\end{tabular}


Responden dengan suku Batak dan Bali sama-sama memiliki persentase terendah, yaitu masing-masing sebesar 1,85 persen. Meskipun suku menjadi salah satu karakteristik responden, namun pada penelitian ini tidak dianalisis pengaruh suku dalam mengonsumsi ikan segar.

Pendapatan rumah tangga adalah jumlah uang yang didapatkan dari semua anggota keluarga atas pekerjaannya dalam kurun waktu satu bulan. Pendapatan rumah tangga dibagi menjadi tiga golongan, yang bertujuan untuk melihat pendapatan rumah tangga dari golongan yang terendah sampai golongan tertinggi. Berdasarkan Tabel 1 dapat diketahui bahwa dominan (42,59\%) rumah tangga berada pada tingkat pendapatan Rp2.000.000,00-Rp4.000.000,00/bulan, dan hanya 5,56 persen berada pada tingkat pendapatan Rp8.000.001,00 -Rp10.000.000,00/bulan dan lebih dari Rp10.000.000,00.

\section{Jumlah Konsumsi Ikan Segar}

Konsumsi ikan segar oleh rumah tangga merupakan kegiatan pemenuhan kecukupan gizi. Ikan segar merupakan salah satu sumber protein hewani yang tinggi dan mudah didapat dengan harga yang relatif terjangkau oleh masyarakat dibandingkan dengan daging ayam, daging sapi, maupun jenis hewan lainnya. Responden pada penelitian ini mengonsumsi ikan segar dengan jumlah yang berbeda-beda per bulannya. Perbedaan jenis ikan segar ini diduga memengaruhi perbedaan tingkat konsumsi ikan segar oleh konsumen rumah tangga di Kota Bandar Lampung. Sebaran konsumsi ikan segar per bulan per kapita di Kota Bandar Lampung tahun 2019 dapat dilihat pada Tabel 2.

Tabel 2. Sebaran konsumen ikan segar di Kota Bandar Lampung berdasarkan jumlah konsumsi ikan segar per bulan per kapita, tahun 2019

\begin{tabular}{lcc}
\hline $\begin{array}{l}\text { Jumlah Protein } \\
\text { (gram/bulan) }\end{array}$ & $\begin{array}{c}\text { Jumlah Responden } \\
\text { (orang) }\end{array}$ & $\begin{array}{c}\text { Persentase } \\
(\%)\end{array}$ \\
\hline $401,60-1.001,06$ & 24 & 44,44 \\
$1.001,07-1.600,53$ & 24 & 44,44 \\
$1.600,53-2.200,00$ & 6 & 11,12 \\
\hline Jumlah & 54 & 100,00 \\
\hline Rata-rata konsumsi & & \\
ikan segar per & 798,36 gram protein \\
kapita/bulan & & \\
\hline Rata-rata konsumsi & & \\
ikan segar per & 26,61 gram protein \\
kapita/hari & & \\
\hline
\end{tabular}

Berdasarkan Tabel 2 diketahui bahwa rata-rata konsumsi ikan segar per kapita/hari adalah 26,61 gram protein, sedangkan rata-rata konsumsi ikan segar per kapita/bulan adalah 798,36 gram protein. Jumlah tersebut lebih besar dibandingkan dengan rata-rata konsumsi ikan segar per kapita/hari penduduk (rumah tangga) Kota Bandar Lampung, yaitu 7,21 gram protein (Badan Pusat Statistik Kota Bandar Lampung 2017). Berdasarkan hasil tersebut dapat dikatakan bahwa jumlah konsumsi protein ikan segar ini masih belum mencapai standar yang ditetapkan oleh Organisasi Pangan dan Pertanian Dunia (FAO), yaitu 71 gram protein per kapita per hari atau 26 kilogram protein per kapita per tahun (Virgantari dkk 2011).

\section{Pola Konsumsi Ikan Segar}

Pola konsumsi merupakan banyaknya jumlah pangan, secara tunggal maupun beragam, yang dikonsumsi seseorang atau sekelompok orang yang bertujuan untuk memenuhi kebutuhan fisiologis, psikologis, dan sosiologis (Sediaoetomo 1996). Pola konsumsi ikan segar dalam penelitian ini dapat diketahui dengan cara wawancara menggunakan metode recall (menanyakan ulang) kepada responden tentang ikan segar yang dikonsumsi selama satu bulan terakhir. Pola konsumsi dalam penelitian ini dapat diketahui melalui empat hal, yaitu jenis ikan, frekuensi konsumsi, jumlah pembelian dan tempat pembelian. Pola konsumsi ikan segar oleh konsumen rumah tangga di Kota Bandar Lampung dijelaskan sebagai berikut.

\section{Jenis Ikan Segar}

Jenis ikan segar adalah ragam ikan segar yang dikonsumsi responden selama satu bulan terakhir. Ikan segar yang dikonsumsi meliputi 8 jenis ikan air tawar dan 5 jenis ikan laut. Jenis ikan yang paling banyak $(37,04 \%)$ dikonsumsi oleh responden adalah ikan lele, sedangkan yang paling sedikit dikonsumsi oleh responden adalah ikan bawal dan ikan bandeng, masing-masing sebesar 1,85 persen dan 1,85 persen.

\section{Frekuensi Konsumsi Ikan Segar}

Frekuensi konsumsi ikan segar menggambarkan seberapa sering konsumen rumah tangga dalam mengonsumsi ikan segar dalam jangka waktu satu bulan. Berdasarkan Tabel 3 diketahui bahwa dominan $(53,70 \%)$ responden mengonsumsi ikan segar pada frekuensi 12-17 kali per bulan, sedangkan responden yang paling sedikit 
mengonsumsi ikan segar pada frekuensi 30-35 kali per bulan dan 36-41 kali per bulan masing-masing 3,70 persen. Menurut Khomsan (2003), frekuensi makan yang baik adalah 3 kali dalam sehari, yaitu makan pagi, siang, dan malam. Apabila kita hanya makan satu atau dua kali per hari akan sulit secara kuantitas dan kualitas untuk memenuhi kebutuhan gizi. Bila frekuensi konsumsi ikan segar dikaitkan dengan pendapat Khomsan (2003), responden yang dominan mengonsumsi ikan segar pada frekuensi 12-17 kali per bulan hanya makan tiga kali sehari dalam 4 sampai 6 hari. Artinya konsumen ikan segar di Kota Bandar Lampung belum memenuhi standar makan ikan segar tiga kali sehari.

\section{Jumlah Pembelian}

Jumlah pembelian ikan segar adalah banyaknya ikan segar yang dibeli oleh responden selama satu bulan. Ikan segar yang dibeli oleh konsumen ikan segar di Kota Bandar Lampung pada penelitian ini terdiri dari ikan air tawar dan ikan laut. Jumlah pembelian ikan segar diukur dalam satuan kilogram per bulan. Berdasarkan Tabel 3 diketahui bahwa responden dominan $(42,60 \%)$ membeli ikan segar dengan jumlah pembelian 4,10-6,00 $\mathrm{kg} /$ bulan, sedangkan yang terendah $(24,07 \%)$ membeli ikan segar dengan jumlah pembelian $6,10-8,00 \mathrm{~kg} / \mathrm{bulan}$. Sebaran konsumen ikan segar di Kota Bandar Lampung berdasarkan pola konsumsi dapat dilihat pada Tabel 3.

\section{Tempat Pembelian}

Berdasarkan hasil penelitian diketahui bahwa mayoritas $(94,44 \%)$ responden membeli ikan segar di pasar tradisional di sekitar wilayah masingmasing, antara lain di Pasar Sukarame, Pasar Tani Kemiling, dan Pasar Panjang, dan hanya 3,70 persen responden yang memilih membeli ikan segar di pedagang ikan pinggir jalan, serta sebesar 1,85 persen responden memilih membeli ikan segar di pedagang keliling. Alasan responden memilih pasar tradisional sebagai tempat pembelian ikan segar karena responden dominan berprofesi sebagai ibu rumah tangga, dan harga di pasar tradisional relatif lebih murah dibandingkan dengan tempat lain.

\section{Faktor - faktor yang Memengaruhi Konsumsi Ikan Segar di Kota Bandar Lampung}

Jumlah konsumsi ikan segar oleh konsumen rumah tangga dalam penelitian ini diukur dalam satuan gram protein, artinya berapa banyak konsumsi gram protein pada ikan segar.
Tabel 3. Sebaran rumah tangga ikan segar di Kota Bandar Lampung berdasarkan pola konsumsi tahun 2019

\begin{tabular}{|c|c|c|}
\hline Pola Konsumsi & $\begin{array}{l}\text { Jumlah } \\
\text { (orang) }\end{array}$ & Persentase $(\%)$ \\
\hline \multicolumn{3}{|c|}{ Jenis ikan segar (tawar) } \\
\hline Lele & 20 & 37,04 \\
\hline Mas & 13 & 24,07 \\
\hline Patin & 9 & 16,67 \\
\hline Bawal & 1 & 1,85 \\
\hline Nila & 13 & 24,07 \\
\hline Gurame & 5 & 9,26 \\
\hline Gabus & 4 & 7,41 \\
\hline Bandeng & 1 & 1,85 \\
\hline \multicolumn{3}{|c|}{ Jenis ikan segar (laut) } \\
\hline Simba & 2 & 3,70 \\
\hline Layang & 10 & 18,52 \\
\hline Kembung & 19 & 35,19 \\
\hline Teri & 9 & 16,67 \\
\hline Tongkol & 11 & 20,37 \\
\hline \multicolumn{3}{|c|}{ Frekuensi (kali/bulan) } \\
\hline $0-5$ & 0 & 0,00 \\
\hline $6-11$ & 12 & 22,22 \\
\hline $12-17$ & 17 & 31,48 \\
\hline $18-23$ & 12 & 22,22 \\
\hline $24-29$ & 9 & 16,67 \\
\hline $30-35$ & 2 & 3,70 \\
\hline $36-41$ & 2 & 3,70 \\
\hline Jumlah & 54 & 100,00 \\
\hline \multicolumn{3}{|c|}{ Jumlah pembelian ikan segar (Kg/bulan) } \\
\hline $2,00-4,00$ & 18 & 33,33 \\
\hline $4,10-6,00$ & 23 & 42,60 \\
\hline $6,10-8,00$ & 13 & 24,07 \\
\hline Jumlah & 54 & 100,00 \\
\hline
\end{tabular}

Untuk mengetahui faktor-faktor yang memengaruhi jumlah konsumsi ikan segar dilakukan analisis regresi linier berganda dengan bantuan program IBM SPSS Statistic 20.

Model konsumsi ikan segar terdiri dari variabel bebas (independent) dan variabel terikat (dependent). Variabel terikat (Y) adalah jumlah konsumsi ikan segar selama satu bulan dalam satuan gram protein dan variabel bebasnya adalah harga ikan segar $\left(\mathrm{X}_{1}\right)$, harga telur ayam $\left(\mathrm{X}_{2}\right)$, pendapatan keluarga $\left(\mathrm{X}_{3}\right)$, jumlah anggota keluarga $\left(\mathrm{X}_{4}\right)$, tingkat ekonomi bawah $\left(\mathrm{D}_{1}\right)$, dan tingkat ekonomi menengah $\left(\mathrm{D}_{2}\right)$.

Untuk menguji hasil regresi agar tidak menghasilkan persamaan yang bias, maka dilakukan uji asumsi klasik. Uji asumsi klasik tersebut meliputi uji multikolinearitas dan heteroskedastisitas (Ghozali 2009). Uji multikolinearitas dan heteroskedastisitas dapat diketahui setelah dilakukan regresi dengan aplikasi 
IBM SPSS Statistic 20. Uji heteroskedastisitas dapat diketahui dengan cara mengamati histogram dan diagram scatter plot. Jika pada diagram tersebut bulatan-bulatan menyebar bebas dengan baik, maka model tidak terkena heteroskedastisitas. Berdasarkan hasil uji, bulatan-bulatan menyebar bebas dengan baik, hanya saja ada 6 bulatan yang terletak jauh dari penyebaran, serta pada histogram terlihat bahwa balok-balok diagram berada pada satu jalur, meskipun terdapat satu balok yang keluar dari jalur.

Uji multikolinearitas dapat diketahui dengan melihat nilai VIF. Jika nilai $\mathrm{VIF}<10$, maka tidak terjadi multikolinearitas. Berdasarkan hasil regresi, nilai VIF yang ada pada setiap variabel bebas $\left(\mathrm{X}_{\mathrm{i}}\right)$ adalah $<10$, maka tidak terjadi gejala multikolonearitas pada model tersebut. Berdasarkan uji multikolinearitas dan heteroskedastisitas, data yang diolah dalam regresi linear berganda tidak terdapat masalah atau penyakit, sehingga layak untuk dianalisis.

Selanjutnya, terdapat tiga variabel bebas yang nyata berpengaruh terhadap jumlah konsumsi ikan segar di Kota Bandar Lampung tahun 2019. Variabel tersebut adalah harga ikan segar $\left(X_{1}\right)$ dan tingkat ekonomi bawah $\left(\mathrm{D}_{1}\right)$ dengan tingkat kepercayaan 99 persen. Berdasarkan hasil analisis regresi tersebut, maka secara matematis fungsi faktor-faktor yang memengaruhi jumlah konsumsi ikan segar di Kota Bandar Lampung tahun 2019 adalah:

$$
\begin{aligned}
& \text { Apabila } \mathrm{D}_{1}=1, \mathrm{D} 2=0 \\
& \mathrm{Y}=34,644+0,704 \mathrm{X}_{1}+0,004 \mathrm{X}_{2}+7,582 \mathrm{E}- \\
& 006 \mathrm{X} 3+0,515 \mathrm{X} 4+186,580 \mathrm{D} 1-50,029 \mathrm{D}_{2} \\
& \mathrm{Y}=34,644+0,704 \mathrm{X}_{1}+0,004 \mathrm{X}_{2}+7,582 \mathrm{E}- \\
& 006 \mathrm{X} 3+0,515 \mathrm{X} 4+186,580(1)-50,029(0) \\
& \mathrm{Y}=221,224+0,704 \mathrm{X}_{1}+0,004 \mathrm{X}_{2}+7,582 \mathrm{E}- \\
& 006 \mathrm{X} 3+0,515 \times 4
\end{aligned}
$$$$
\text { Apabila } \mathrm{D}_{1}=0, \mathrm{D} 2=1
$$$$
\mathrm{Y}=34,644+0,704 \mathrm{X}_{1}+0,004 \mathrm{X}_{2}+7,582 \mathrm{E}-
$$$$
006 \mathrm{X} 3+0,515 \mathrm{X} 4+186,580 \mathrm{D} 1-50,029 \mathrm{D}_{2}
$$$$
\mathrm{Y}=34,644+0,704 \mathrm{X}_{1}+0,004 \mathrm{X}_{2}+7,582 \mathrm{E}-
$$$$
006 \mathrm{X} 3+0,515 \mathrm{X} 4+186,580(0)-50,029(1)
$$$$
\mathrm{Y}=-15,385+0,704 \mathrm{X}_{1}+0,004 \mathrm{X}_{2}+7,582 \mathrm{E}-
$$$$
006 \mathrm{X} 3+0,515 \mathrm{X} 4
$$

Apabila D1 dan D2 = 0

$$
\begin{aligned}
\mathrm{Y}= & 34,644+0,704 \mathrm{X}_{1}+0,004 \mathrm{X}_{2}+7,582 \mathrm{E}- \\
& 006 \mathrm{X} 3+0,515 \mathrm{X} 4+186,580 \mathrm{D} 1-50,029 \mathrm{D}_{2} \\
\mathrm{Y}= & 34,644+0,704 \mathrm{X}_{1}+0,004 \mathrm{X}_{2}+7,582 \mathrm{E}- \\
& 006 \mathrm{X} 3+0,515 \mathrm{X} 4+186,580(0)-50,029(0) \\
\mathrm{Y}= & 34,644+0,704 \mathrm{X}_{1}+0,004 \mathrm{X}_{2}+7,582 \mathrm{E}- \\
& 006 \mathrm{X} 3+0,515 \mathrm{X} 4
\end{aligned}
$$

Uraian faktor-faktor yang memengaruhi jumlah konsumsi ikan segar di Kota Bandar Lampung adalah:

\section{Harga Ikan Segar $\left(\mathbf{X}_{1}\right)$}

Harga ikan segar nyata berpengaruh terhadap jumlah konsumsi ikan segar dengan tingkat kepercayaan 99 persen. Nilai koefisien antara variabel harga ikan segar dengan jumlah konsumsi ikan segar bernilai positif yaitu sebesar 0,704 . Hal tersebut menjelaskan bahwa jika harga ikan segar meningkat sebesar 1 satuan, maka akan meningkatkan konsumsi ikan segar sebesar 0,704 satuan. Berdasarkan teori permintaan seharusnya koefisien harga ikan segar bernilai negatif, sehingga jika harga ikan segar turun, maka permintaan ikan segar naik. Hal ini sejalan dengan penelitian Purba (2004) bahwa konsumsi daging dipengaruhi oleh harga daging tersebut dengan nilai koefisien regresi yang sesuai dengan teori permintaan. Namun, pada penelitian ini konsumen rumah tangga mengonsumsi ikan segar berdasarkan kesukaan dan kebiasaan.

\section{Tingkat Ekonomi Bawah $\left(D_{1}\right)$}

Variabel tingkat ekonomi bawah nyata berpengaruh terhadap jumlah konsumsi ikan segar dengan tingkat kepercayaan sebesar 99 persen. Bila responden termasuk ke dalam tingkat ekonomi bawah, maka akan meningkatkan konsumsi ikan segar sebesar 221,24 satuan. Ikan segar merupakan sumber protein hewani utama bagi rumah tangga tingkat ekonomi bawah, sedangkan bagi tingkat ekonomi menengah dan atas, ikan segar menjadi barang inferior yang semakin ditinggalkan seiring dengan meningkatnya pendapatan. Hasil regresi linier berganda faktorfaktor yang memengaruhi konsumsi ikan segar di Kota Bandar Lampung tahun 2019 dapat dilihat pada Tabel 4. 
Tabel 4. Hasil regresi linier berganda faktor-faktor yang memengaruhi konsumsi ikan segar di Bandar Lampung, tahun 2019

\begin{tabular}{lrl}
\hline Variabel & Koefisien & Sig \\
\hline Konstanta $(\mathrm{C})$ & 34,644 & 0,802 \\
Harga ikan segar $\left(\mathrm{X}_{1}\right)$ & 0,704 & 0,000 \\
Harga telur ayam $\left(\mathrm{X}_{2}\right)$ & 0,004 & 0,953 \\
Pendapatan keluarga $\left(\mathrm{X}_{3}\right)$ & $7,582 \mathrm{E}-006$ & 0,395 \\
Jumlah anggota keluarga $\left(\mathrm{X}_{4}\right)$ & 0,515 & 0,980 \\
Tingkat ekonomi bawah $\left(\mathrm{D}_{1}\right)$ & 186,580 & 0,004 \\
Tingkat ekonomi menengah $\left(\mathrm{D}_{2}\right.$ & 50,029 & 0,320 \\
F-hitung & 22,461 & 0,000 \\
$R$-squared $\left(R^{2}\right)$ & 0,741 & \\
Adj $R$-Squared & 0,708 & \\
\hline
\end{tabular}

Faktor-faktor yang tidak memengaruhi konsumsi ikan segar di Kota Bandar Lampung antara lain harga telur ayam $\left(\mathrm{X}_{2}\right)$, pendapatan keluarga $\left(\mathrm{X}_{3}\right)$, dan tingkat ekonomi menengah $\left(\mathrm{D}_{2}\right)$. Variabel harga telur ayam $\left(\mathrm{X}_{2}\right)$ yang tidak memengaruhi konsumsi ikan segar di Kota Bandar Lampung sejalan dengan penelitian Parulian, Lestari dan Adawiyah (2014) bahwa harga telur ayam tidak memengaruhi konsumsi daging sapi.

\section{KESIMPULAN}

Berdasarkan hasil penelitian ini, rata-rata konsumsi ikan segar oleh konsumen di Kota Bandar Lampung adalah 26,61 gram protein per kapita per hari atau 798,36 gram/bulan dengan anjuran 71 gram protein per kapita per hari. Pola konsumsi ikan segar di Kota Bandar Lampung terdiri dari jenis ikan segar yang dikonsumsi adalah dominan ikan lele; frekuensi ikan segar yang dominan adalah 12-17 kali per bulan; jumlah pembelian ikan segar yang dominan adalah 4,10-6,00 kg per bulan; dan tempat pembelian ikan segar oleh konsumen di Kota Bandar Lampung adalah pasar tradisional. Faktor-faktor yang memengaruhi konsumsi ikan segar di Kota Bandar Lampung adalah harga ikan segar dan tingkat ekonomi bawah.

\section{DAFTAR PUSTAKA}

BPS [Badan Pusat Statistik]. 2007. Pola Konsumsi Sebagai Proporsi Pengeluaran Rumah Tangga. Badan Pusat Statistik. Jakarta.

BPS [Badan Pusat Statistik]. 2017. Pengeluaran Masyarakat Indonesia Untuk Makanan dan
Bukan Makanan Tahun 2016. Badan Pusat Statistik. Jakarta.

BPS [Badan Pusat Statistik] Kota Bandar Lampung. 2017. Bandar Lampung Dalam Angka 2015-2016. Badan Pusat Statistik Kota Bandar Lampung. Bandar Lampung.

Budianto AK. 2009. Dasar-Dasar Ilmu Gizi. UMM Press. Malang.

Ghozali I. 2009. Aplikasi Analisis Multivariate dengan Program SPSS. Universitas Diponegoro Press. Semarang.

Indiani Y. 2015. Gizi dan Pangan. Aura Publisher. Bandar Lampung.

Kementerian Kesehatan Republik Indonesia. 2017. Makan Ikan Untuk Generasi Sehat. http://www.depkes.go.id/article/view/1705150 0001/ayo-makan-ikan-untuk-generasi-sehatdan-cerdas.html. [3 Desember 2017].

Khomsan A. 2003. Peranan Pangan dan Gizi untuk Kualitas Hidup. Gramedia Pustaka Utama. Jakarta.

Nasir M. 1988. Metode Penelitian. Ghalia Indonesia. Jakarta.

Parulian J, Lestari DAH, dan Adawiyah R. 2014. Pola konsumsi daging sapi oleh rumahtangga di Bandar Lampung. Jurnal Ilmu Ilmu Agribisnis, 2 (4): $1-8$. http://jurnal.fp.unila.ac.id/index.php/JIA/articl e/view/991/896. [2 Desember 2017].

Purba RP. 2004. Analisis perubahan pola konsumsi daging di Indonesia : tingkat partisipasi dan tingkat konsumsi daging menurun saat krisis dan kembali meningkat pasca krisis. https://repository.ipb.ac.id/handle/123456789/ 8644\&sa. [26 Juni 2019].

Sediaoetomo AD. 1996. Ilmu Gizi untuk Mahasiswa dan Profesi. Jilid I. Dian Rakyat. Jakarta.

Sugiarto D, Siagian LT, Sunaryanto dan Oetomo DS. 2001. Teknik Sampling. Gramedia Pustaka Utama. Jakarta

Sukiyono K, Cahyadinata, dan Sriyoto. 2008. Status Wanita dan Ketahanan Pangan Rumah Tangga Nelayan dan Petani Padi di Kabupaten Muko-Muko Provinsi Bengkulu. Jurnal Agro Ekonomi. 26 : 191-207.

Virgantari F, Daryanto A, Harianto, Kuntjoro SU. 2011 Dinamika Konsumsi Produk Perikanan Di Indonesia. Jurnal Institut Pertanian Bogor. IPB. 9 hal. 